\title{
Prevalence and predictors of self-medication among University students in Ethiopia: A systematic review and Meta-analysis
}

Getahun Fetensa ( $\nabla$ fetensagetahun@gmail.com )

Wollega University

Tadesse Tolossa

Wollega University

Werku Etafa Ebi

Wollega University

\section{Research article}

Keywords: Ethiopia, Meta-analysis, Self-medication, Students, Systematic review

Posted Date: August 19th, 2019

DOI: https://doi.org/10.21203/rs.2.13118/v1

License: () (i) This work is licensed under a Creative Commons Attribution 4.0 International License. Read Full License

Version of Record: A version of this preprint was published at Journal of Pharmaceutical Policy and Practice on December 1st, 2021. See the published version at https://doi.org/10.1186/s40545-021-00391-y. 


\section{Abstract}

Background Self-medication is the global issue especially on those having access and education about medication irrespective of its side effect. It has a significant impact on resistance and medication-related complication. There are limited and inconsistent studies regarding self-medication practice in Ethiopia. The aim of this systematic review and meta-analysis was to estimates the pooled prevalence of self-medication and its predictors among Ethiopian university students. Method A systematic review and meta-analysis were conducted to assess the prevalence and predictors of self-medication among university students in Ethiopia. We searched literature from the databases of Medline, Hinari, Scopes, PubMed CINAHL, PopLine, MedNar, Embase, Cochrane library, the JBI Library, the Web of Science, Google Scholar and manual search. A total of nine studies reporting the prevalence of self-medication among university students were included. Data were extracted using a standardized data extraction format prepared in Microsoft Excel and the analysis was done using STATA 14 statistical software. To assess heterogeneity, 12 test was used since the included studies exhibit high heterogeneity, a random effect metaanalysis model was computed to estimate the pooled prevalence of self-medication. In another way, the association between predictor variables, and selfmedication practice were examined. Result A total of 3513 study respondents from nine studies in Ethiopia published between $2010-2017$ were included in the study. The result of our study reveals that a pooled prevalence of self-medication among university students was $45.61 \%(95 \% \mathrm{Cl}$ : $30.66,60.57)$. Included studies have a sample size ranged from 250 to 548 with lowest prevalence (19.81\%) of self-medication from University of Gondar, whereas the highest prevalence (77.01\%) recorded in a study conducted at Arsi University. Conclusion Prevalence of Ethiopian university students was $45.61 \%$, which is very high with the current global health problem with Anti-microbial resistance increment and other toxicity. In addition to this in this study, the association between selfmedication and year of study was insignificant and statistically significant with the sex of participants and income level. Systemic review registration PROSPERO International prospective register of systematic reviews: CRD42018099975

\section{Background}

Self-medication is either safe or not is a worldwide issue [1]. Based on socioeconomic and socio-demographic factors, the types, extent, and reason for selfmedication can vary from country to country along with its effect [2]. Source of information influence practice of self-medication [3,4].

Self-medication may arise from different factors that can be categorized as health professional factor and consumer's factor. Some of the self-medicating groups complain as they are not comfortable with health professional behavior and they don't have enough confidence on knowledge of health professional while the others need to practice participation of their health management [5]. There are two different perceptions by consumers from consumer's side. There two views first view those agree with self-medication not safe, and the rest is opposite [1]. Some students perceive self-care is part of self-care [6]. A significant portion of the students said that they had self-prescribed a drug based on the previous doctor's prescription for the same disease and previous experience. The condition might rise from in proper advice of professional at last contact [7, 8]. The majority of respondents practiced self-medication either because their illness was not serious or they had prior experience with the drug [9]. The Majority of students obtain self-medication from pharmacies that indicate responsiveness of pharmacy professionals to give medications without a prescription [10]. Medicine that consumed by consumers have burdens on an individual. Inappropriate self-medication may lead to delay diagnosis of a serious health problem and its economic burden on the patient and the health care system that predispose patients for needless medicines. The problem might harm his health, lead to the side effect and adverse effects of home remedies and herbs, it might worse n's the patient's condition and the patient's might suffer longer than necessary, and missed many work days[11].

Self-medication practice of university students is related with some factors like being female, being the undergraduate and increased year of study to be practiced in high prevalence $[12,13,5,14,2,15,16]$.

Prevalence of self-medication among health science students in India was $92.7 \%$ [13]. While other study from north India among nursing students was $88.24 \%$ [17], Brazil among nursing students $76.0 \%$ (18), and Kuwait among medical students was $97.8 \%$ [19]. On other systemic review from Ethiopia indicates selfmedication varied from $12.8 \%$ to $77.1 \%[20]$, Iran university was 65\%[15], Eastern Saudi Arabia indicates $90.5 \%[21]$, medical students in Coastal South India 78.6\%[22], 86\% United Arab Emirates[23], and 94\% among university students in Oman[9].

So many factors were directly related to self-medication among university students. Of which illness like headache $(90.1 \%), 84.7 \%$ for menstruation discomfort $60.3 \%$ constipation, fever, cough, abdominal discomfort[19,24, 25,2,15,9,26].Therefore this study is aimed at identifying factors contributing to selfmedication and its prevalence in population groups that are assumed to have the most frequency of self-medication. The study might also assume to have good input for policy makers and researchers as baseline data for further study.

\section{Methods}

\section{Search Strategy}

This systemic review and meta-analysis was conducted to assess the pooled prevalence of self-medication and factors associated with self-medication among university students in Ethiopia. We checked for the presence of the existing systematic reviews and meta-analysis on similar topic using the Cochrane library to avoid duplication at the beginning. We included only published and all observational studies in this review. All potentially relevant studies in the following databases: Medline, Hinari, Scopes, PubMed CINAHL, PopLine, MedNar, Embase, Cochrane library, the JBI Library, the Web of Science and Google Scholar were included in the review. We accessed all studies since 2010 using the following search terms ${ }^{\text {a Prevalence }}{ }^{\circ} \mathrm{OR}^{\mathrm{a}} \mathrm{Epidemiology}^{\circ} \mathrm{AND}{ }^{\mathrm{a}}$ selfmedication ${ }^{\circ} \mathrm{OR}{ }^{\text {a }}$ self-medication ${ }^{\circ} \mathrm{OR}{ }^{\text {a }}$ self-prescription ${ }^{\circ}$ AND ${ }^{a}$ Ethiopian university ${ }^{\circ}$.

We included only studies published in English language. All published articles up to June 2018 were included in the review. List of references from identified articles were also reviewed to identify additional articles. Search strategy was prepared and modified for the various databases using important Boolean 
operators with initial keywords ( ${ }^{\text {PPrevalence }}{ }^{\circ}$ OR ${ }^{a}$ Epidemiology ${ }^{\circ}$ AND a self-medication ${ }^{\circ}$ OR ${ }^{a}$ self-medication ${ }^{\circ}$ OR $^{\text {a }}$ self-prescription ${ }^{\circ}$ AND ${ }^{\text {a Ethiopian }}$ university ${ }^{\circ}$.

Literature was downloaded and imported to Mendley desktop reference citation to maintain and manage citation and facilitate review process and the Preferred Reporting Items for Systematic Reviews and Meta-Analyses (PRISMA) guideline was used during the review process. The searching of articles were done from June-January 2018.

\section{Selection and Eligibility criteria}

This systematic review included studies that were conducted on the prevalence of self-medication and associated factors in Ethiopia and participants were university students. The review included all studies that conducted in Ethiopia with sample size greater than 250 , all observational studies and studies published in English language. We included all studies that were published in the form of journal articles. We excluded studies conducted outside university students, unpublished studies and studies with the methodological problems and review articles.

\section{Exclusion criteria}

Before exclusion, we have examined the eligibility of the studies by reading their titles and abstracts. After reading the abstracts, if the studies are relevant to our review, we screened the full texts. During the article selection process, studies, which were not fully accessed after reading the titles and abstracts, were excluded. However, before excluding the articles, we were attempted to contact the primary author at least two times through email. The reason for the exclusion of these articles is that we are unable to assess the quality of each article in the absence of their full texts. In addition, studies, which did not report our outcome of interest, were excluded after reviewing their full versions.

\section{Study Outcomes}

This meta-analysis and systematic review considered two main outcome. The primary outcome was to determine the prevalence of self-medication among university students. The second outcome of this study was to identify factors associated with self-medication. The prevalence was calculated by dividing the number of participants engaged in self-medication practice to the total number of participants who have been included in the study (sample size) multiplied. For the second outcome, we determined factors associated with self-medication in the form of the odds ratio. Three major factors assessed by each primary studies were selected to explore their association with self-medication. For each factor, we calculated the odds ratio based on binary outcomes from the primary studies. The factors assessed for this review was sex (male versus female), income per month ( $\leq 500$ versus $\geq 501)$ and year of study $(\leq 2$ years versus $\geq 3$ years)

\section{Quality assessment and Data extraction}

The reference management software (Endnote version X7.2) was used to combine database search results and to remove duplicate articles manually. Two reviewers independently assessed articles prior to inclusion in the final review using Joanna Briggs Institute Meta-Analysis of Statistics Assessment and Review Instrument (JBI-MAStARI) instrument for critical appraisal. This tool contains a separate appraisal checklist for each type of the study design. For the primary outcome, the data extraction format included first author, region in the country where the studies were conducted, the university where the studies were carried out, publication year, study design, sample size, response rate and prevalence/practice of self-medication. For the second outcome (associated factors), the data extraction format was prepared for each specific associated factors. For each associated factors, to calculate the odds ratio, we were extracted the data from the primary studies in the form of two by two tables. Any disagreements between the authors during extractions discussed and solved through consensus. Studies with quality assessment score of 7 and above, and studies with response rate of $85 \%$ and above were included in the final review.

\section{Statistical Analysis and Synthesis}

Before analysis, necessary data from each original study were extracted using Microsoft Excel spreadsheet form. The extracted data were imported to and analyzed using STATA version 14.1 statistical software. We generated the logarithm and standard error of the odds ratio (OR) for each original study using "generate" command in STATA. We used cochrane's Q statistic (chi-square), $\mathrm{I}^{2}$ and p-values to check for heterogeneity of the studies' outcomes. Forest plots were used to present the results of analysis and to visualize the presence of heterogeneity. In addition Point prevalence, as well as $95 \%$ confidence intervals, was presented in a forest plot format. From the result of statistical test, significant heterogeneity was found among included studies $\left(I^{2}=99 \%, p<0.001\right)$ and a random effects meta-analysis model was performed to estimate the Der Simonian and Laird's pooled effect. In addition, we conducted sub-group analysis (based on the region where the were conducted) to identify source of heterogeneity and statistically significant results were declared in the presence of heterogeneity. Funnel test was used to check publication bias. Further, we checked the statistical significance of publication bias using Egger tests. A p-value less than 0.05 was used to declare the presence of publication bias.

\section{Results}

\section{Selection and Identification of Studies}

We found a total of 812 published studies throughout our search that conducted from 2010 to 2017 in different regions of the country. Of the total identified, 415 duplicate records were removed and 346 papers were excluded after screening by title and abstract. We assessed the full text of remaining the 31 studies for eligibility, of which 23 studies were excluded because they failed to meet the eligibility criteria. Finally, 9 studies were scored seven and above on the JBI quality appraisal eligibility criteria and included in meta-analysis. We used Preferred Reporting Items for Systematic Reviews and Meta-Analyses (PRISMA) flow diagram to present the systematic review overview (Figure 1). 
The nine included studies were cross-sectional study design and published between 2010 to 2017. In the current meta-analysis, 3513 study participants were involved to determine the pooled prevalence of self-medication among university students. Regarding sample size, the minimum sample size was $250[29]$ and the maximum was 548 [28]. The lowest prevalence (19.8\%) of self-medication was reported in studies conducted in Gondar University, Amhara region [27], whereas the highest prevalence (77.01\%) was reported in a study conducted in Arsi University, Oromia region [28]. In the present meta-analysis, six Ethiopian Universities were represented. Four of the studies were from Amhara [29, 27, 30, 31], three from Oromia [28, 32, 34], and two from Tigray [25, 33]. Regarding the response rate, almost all studies had a response rate of greater than $90 \%$, and one studies did not state the response rate [27]. Among included studies Six of them used stratified sampling technique $[27,31,28,25,33,31,30]$ two of them used simple random sampling [32,29], and one used convenient sampling techniques [34] (Table 1).

\section{Reason for self-medication, Recall period, Rational for the use of self-medication and most commonly used drug/drug group.}

The result from studies indicates that, disorders like fever, headache, cough, common cold, gastric pain, diarrhea, fever and chills, chest pain, constipation, eye disease, gastrointestinal disease, respiratory tract infection, eye disease, skin diseases or injury, sexually transmitted disease, maternal/menstrual, diarrhea, nasal congestion, toothache, and sore throat were the major reasons for the students to practice self-medication. Among above-stated reason within all studies headache was the most predominant reason with 25.8\%-69.1\% across all selected studies with recall period from 2-6 month of duration. The drug groups range from antibiotics type, analgesics, anti-acids, and vitamins. There were different reasons for respondents across studies. Accordingly, reason like the disease is not serious, poor quality of service, emergency use, prior experience, took pharmacology course, saves time, less expensive, do not trust health professionals, obtaining drugs easily, being embarrassed to tell about the disease were some of it (Table 2).

\section{Source of information and source of drugs for self-medication}

The study had reviewed for the source of information and source of medicine from 9 studies that fulfills inclusion criteria. Accordingly, the source of information ranges from traditional healers to pharmacists while the source of the drug varies from friends or family left over to government pharmacy (Table3).

\section{Prevalence of self-medication}

The nine included studies revealed that a pooled prevalence of self-medication among university students in Ethiopia was $45.61 \%$ (95\%Cl: $30.66,60.57$ ) (Figure 2). High heterogeneity was observed across the included studies ( $12=99, p<0.001)$. Therefore, a random effect meta-analysis model was executed to estimate the pooled prevalence of self-medication among university students in Ethiopia. From this meta-analysis, the highest prevalence was $77.01 \%$ (95\% Cl: 73.48, 80.53) study conducted in Arsi University, Oromia region [28] whereas the lowest prevalence of 19.81\% (Cl: 15.97, 23.65) was reported in Gondar University, Amhara region [27] (Table 4).

\section{Subgroup analysis and publication bias}

In this meta-analysis, we computed the prevalence of self-medication based on the region where the study were conducted. Accordingly, the prevalence ranged from $37.28 \%$ in Amhara region to $57.78 \%$ in Oromia region (Figure 3). To assess presence of publication bias, funnel plot and Egger test at $5 \%$ significant level were performed. The funnel plot was asymmetry, but Egger test showed that there was no statistically significant publication bias with $\mathrm{p}$-value $=0.762$ (Figure 4).

To identify single study influence on the overall meta-analysis, sensitivity analysis was performed using a random effects model and the result showed there was no strong evidence for the effect of single study influence on the overall meta-analysis (Figure 5).

\section{Determinant of self-medication}

\section{Association between sex and self-medication}

To show association between self-medication and sex of patients, three studies were selected for meta-analysis. One study showed, there was statistically significant association between self-medication and sex in which male students were 2 times more likely to practice self-medication as compared to female students $(\mathrm{OR}=2,95 \%, \mathrm{Cl}: 1.12-3.58)[28]$. Three studies showed that, there was no significant association between medication self-practice and sex of the respondents[30,31,33]. The pooled finding of the analysis showed that, there was no significant association between medication self-practice and sex of the students. Random effect model was computed due to moderate heterogeneity $\left(I^{2}=58.0, p=0.067\right)$ (Figure 6).

\section{Association between self-medication and year of study}

Four studies were included to determine the association between self-medication and year of study. One studies [25] showed a statistically significant association between self-medication and year of study while three studies showed no statistical significance between self-medication and year of study [31, $28,30]$. The pooled findings from these four studies revealed that self-medication was not significantly associated with the year of study (OR: $0.79,95 \% \mathrm{Cl}$ : $0.43,1.35)$. The test showed that there was heterogeneity among included studies $(I 2=96.1 \%$ and $p=0.0001)$ and random effect meta-analysis model was applied to determine the association between self-medication and year of study (Figure 7).

\section{Association between self-medication and income}


Three articles were included in this analysis [30,31,25]. From those involved one study shows a significant association between income and self-medication [31]. From pooled estimation, there was a significant association between self-medication and income. Students who had income less than 500 was $33 \%$ less likely to participate in self-medication as compared to the student who had income greater than 500 (OR: 0.67: 95\% Cl: 0.55, 0.80). In addition, the test showed that there was no heterogeneity between included study $(12=0 \%$ and $p=0.835)$ and fixed effect meta-analysis model was used to determine the association between income level and self-medication (Fig 8).

\section{Discussion}

As far as our knowledge, this meta-analysis is the first of its kind in Ethiopia to estimate the pooled prevalence and predictors of self-medication practice among university students. The result of our study reveals that a pooled prevalence of self-medication among university was $45.61 \%$ (95\%Cl: $30.66,60.57)$. This indicates the professional exposure to drugs and knowledge of illness and treatment choice remains the fundamental contributors to self-medication practice university students [10] as well the use might be due to it is cheap and no medical appointment[18]. This finding is consistent with study conducted on Chinese students [16] and Uganda (43.3\%) [4]. However, our study revealed lower self- medication prevalence than some studies [22, 35, 36, 37, 12, 13, 17, $18,15,38,39,40,41,36,42]$.

The result was slightly lower than survey report from Palestine $33.9 \%$ [43]. Here the difference might be participants from Palestine uses herbal medicine for self-medication while a participant of this study uses all categories of drugs.

\section{Factors associated with self-medication}

The result of the study revealed that self-medication was not significantly associated with the year of study (OR: 0.79, 95\% Cl: $0.43,1.35)$. Random effect meta-analysis model indicates that there was no association between sex and self-medication in four studies [31, 30, 28, 33] that fulfill inclusion criteria. The result was in contrary with the study conducted in Serbia [38], Uganda [4], Sub- Saharan Africa [44], and India [13].

In this studies [27,30,28,25,31,34,33,32] respondents have used anti-biotic ranging from 4.8\%[27] to 66.7\%[34] without prescription. The result in line with study's finding from India which was 63.91\% [45], from Brazil 11.1\%-55.6\% [18], Iran 34.6\% [15], India 39.3\% [22], which is very dangerous in modern health care because of antimicrobial resistance.

In another way, result from this study illustrates that drugs named analgesics/painkillers/anti-pain was used in [27, 29, 34, 31, 33, 32] with the range of 24.4\% [27] to $53.2 \%$ [31]. The result is slightly lower than study result from Oman in which analgesics $96.6 \%$ in male and $95.1 \%$ in female [9], in India $74.8 \%$ [22], Brazil 63.2\% [18], South India 65.8\%[22], Saudi Arabia (55.4\%) [42].

Among nine study fulfilled inclusion criteria 7 of the reported that minor/non-seriousness of the disease was one of the reason six studies [28,25,29,31,33,34,32] with minimum incidence 25.6\% [32] and maximum 81.3\% [34]. Which in line with study result from Egypt [46], Belgium 48.9\% [41]. Here it can be justified that some respondents might look their illness carelessness.

\section{Reason for self-medication}

Headache (64.7\%) [22], similar study from Brazil [18], Iran 85.5\% [15], and in India 64.7\% [22]. Five of studies fulfilling inclusion criteria reported that prior experience/from previous experience of the disease was one of the reasons for self-medication $[28,25,31,34,33]$ ranging from $19.8 \%(31)-69.6 \%[25]$, the result was uniform with study result from Egypt 58.9\% [46], systemic review from developing country [47].

Time saving was one of the reason for consuming self-medication among study respondents $[33,31,28,25]$. The result is consistent with the studies from Brazil [22], Belgium 20.4\% [41], a systemic review of developing country [47].

Cost-effectiveness in $[28,25,31,33,32]$ was the reason for some of the students participated in the study. It is similar with studies result from Belgium $4.37 \%$ [41], a systematic review in developing the country in Africa [47].

A comprehensive search strategies were used in the current systematic review and meta-analysis. A random effects model was used to address the potential variability across studies. The study was based only on the study conducted in the English language limit data from another language. Only published studies were accessed. The studies consider only the result between 2010 and 2017, which may limit variation of data. The result was limited to students only which may not include different reason due to the participants might affect similar socio-economic status.

\section{Conclusion}

Prevalence self-medication among of Ethiopian university students was $45.61 \%$, which is very high with the current global health problem with Anti-microbial resistance increment and other toxicity. This problem was increased due to the easy availability of drugs for self-medication. In addition to this in this study, the association between self-medication and year of study was insignificant, and statistically significant with the sex of participants and income level. We strongly recommend pharmacy vendors to avoid selling the drug without prescription and health professional for counseling on drug usage during ordering drugs. We want to extend our recommendation policy makers for supervision and control in drug vendors' strategic guidance. Moreover, the university administrators in collaboration with other government and non-government organization stakeholders' should establish health education programs about the health effect of self-medication to the university students.

\section{Abbreviations}


Cl-Confidence Interval, df-degree of freedom, NR,-Not Reported, OR-Odds Ratio

\section{Declarations}

\section{Ethical consideration}

Not applicable.

\section{Consent for publication}

Not applicable.

\section{Availability of Data and material}

Not applicable

\section{Competing of interests}

There is no competing of interest

\section{Funding}

Not applicable

\section{Author Contributions}

Conceptualization: GF, Data curation: GF, Formal analysis: GF and TT, Methodology: GF Software: TT, Supervision: TT, Validation and Visualization WE, TT, Writing-review \& editing: GF, TT, WE. All authors reviewed, read and approved the final version of the manuscript.

\section{Acknowledgement}

Not applicable

\section{Authors Details information}

All authors are from Wollega University Institute of health science.

\section{References}

1. Gohar UF, Khubaib S, Mehmood A. Self-medication trends in children by their parents. J Develop Drugs. 2017;6(2):1-7.

2. Abrha SO, Molla F, Melkam W. Self-medication practice: the case of Kolladiba town, north West Ethiopia. Int J Pharma Sci Res. 2014;5(10):670-.

3. Dimabayao CG, Mohammad EK. Prevalence of Self Medication Practice among Nursing Students in Jazan University, Kingdom Of Saudi Arabia. J Nurs Heal Sci. 2016;5(1):11-6.

4. Ocan M, Bwanga F, Bbosa GS, Bagenda D, Waako P, Ogwal-Okeng J, Obua C. Patterns and predictors of self-medication in northern Uganda. PloS one. 2014 Mar 21;9(3):e92323.

5. Alam N, Saffoon N, Uddin R. Self-medication among medical and pharmacy students in Bangladesh. BMC research notes. 2015 Dec;8(1):763.

6. Beyene A, Getachew E, Doboch A, Poulos E, Abdurahman K. Knowledge, attitude and practice of self medication among pharmacy students of rift Valley University, Abichu campus, Addis Ababa, Ethiopia. J Health Med Informat. 2017;8(269):2.

7. Seam M, Bhatta R, Saha B, Das A, Hossain M, Uddin S, Karmakar P, Choudhuri M, Sattar M. Assessing the perceptions and practice of self-medication among Bangladeshi undergraduate

8. Kumari R, Kiran K, Kumar D, Bahl R, Gupta R. Study of knowledge and practices of self-medication among medical students at Jammu. JMS SKIMS. 2012 Dec 27;15(2):141-4.

9. Al Flaiti M, Al Badi K, Hakami WO, Khan SA. Evaluation of self-medication practices in acute diseases among university students in Oman. Journal of Acute Disease. 2014 Jan 1;3(3):249-52.

10. Sharif SI, Bugaighis LM, Sharif RS. Self-Medication practice among pharmacists in UAE. Pharmacology \& Pharmacy. 2015 Sep 10;6(09):428.

11. World health organization TGF. Sudan Journal of Rational Use of Medicine. Sudan J Ration Use Med. 2014;(6).

12. Osemene KP, Lamikanra A. A study of the prevalence of self-medication practice among university students in Southwestern Nigeria. Tropical Journal of Pharmaceutical Research. 2012;11(4):683-9.

13. Johnson DE, Sekhar HS, Alex TE, Kumaraswamy M, Chopra RS. Self medication practice among medical, pharmacy and nursing students. Int J Pharm Pharm Sci. 2016;8(7).

14. Yi S, Peltzer K, Pengpid S, Susilowati IH. Prevalence and associated factors of illicit drug use among university students in the association of southeast Asian nations (ASEAN). Substance abuse treatment, prevention, and policy. 2017 Dec;12(1):9. 
15. Kahnamouei-aghdam F et al.Self-medication prevalence and related factors among medical university students, 2015. International Journal of Basic \& Clinical Pharmacology. 2017 Feb;6(2):373-6.

16. Zhu X, Pan H, Yang Z, Cui B, Zhang D, Ba-Thein W. Self-medication practices with antibiotics among Chinese university students. Public health. 2016 Jan 1;130:78-83.

17. Goel D, Gupta S. Self-medication patterns among nursing students in North India. Reason. 2013 Jan;16:15-24.

18. Gama AS, Secoli SR. Self-medication among nursing students in the state of Amazonas-Brazil. Revista gaucha de enfermagem. 2017;38(1).

19. Hussaini M Al, Mustafa S, Ali S. Journal of Research in Pharmacy Practice Self - medication among undergraduate medical students in Kuwait with reference to the role of the pharmacist. J Res Pharm Pract Orig. 2014;3(1):23-7.

20. Ayalew MB. Self-medication practice in Ethiopia: a systematic review. Patient preference and adherence. 2017; 11:401.

21. Yasein YA, Alghamdi AO. Assessment of Self-Medication Practice Among Undergraduate Medical Students In The Eastern Region, Saudi Arabia.

22. Kumar N, Kanchan T, Unnikrishnan B, Rekha T, Mithra P, Kulkarni V, Papanna MK, Holla R, Uppal S. Perceptions and practices of self-medication among medical students in coastal South India. PloS one. 2013 Aug 28;8(8):e72247.

23. Sharif SI, Ibrahim OH, Mouslli L, Waisi R. Evaluation of self-medication among pharmacy students. American Journal of Pharmacology and Toxicology. 2012;7(4):135-40.

24. Haroun MF, Al-Kayali RS. SELF. MEDICATION AMONG UNDERGRADUATE MEDICAL STUDENTS IN TWO UNIVERSITIES IN SYRIA. International Journal of Pharmaceutical Sciences and Research. 2017 Apr 1;8(4):1881.

25. Eticha T, Araya H, Alemayehu A, Solomon G, Ali D. Prevalence and predictors of self-medication with antibiotics among Adi-haqi campus students of Mekelle University, Ethiopia. Internat J Pharma Sci Res. 2014 Oct;5:678-84.

26. Thadani S, Salman MT, Ahmad A. Knowledge, Attitude and Practice of Self Medication Among Second Year Undergraduate Medical Students. J Rational Pharmacother Res. 2013;1(3):131-4

27. Abay SM, Amelo W. Assessment of Self-medication practices among medical, pharmacy, health science students in Gondar University, Ethiopia. Journal of Young Pharmacists. 2010 Jul 1;2(3):306-10.

28. Bekele SA, Argaw MD, Yalew AW. Magnitude and factors associated with self-medication practices among university students: the case of Arsi University, College of Health Science, Asella, Ethiopia: cross-sectional survey based study. Open Access Library Journal. 2016 Jun 30;3(06):1.

29. Abebe Dilie*, Tenaw Gualu DH and FAZ. Knowledge, attitude and practice of self - medication among health science students at Debre Markos. J Public Heal Epidemiol. 2017;9(5):106-13.

30. Gelayee DA, Binega G. Assessment of Medication Use among University Students in Ethiopia. Hindawi Sci World J. 2017;1-5.

31. Gelayee DA. Self-medication pattern among social Science University students in Northwest Ethiopia. Journal of pharmaceutics. $2017 ; 2017$.

32. Angamo MT, Wabe NT. Knowledge, attitude and practice of self medication in Southwest Ethiopia. Int J Pharm Sci Res. 2012 Apr 1;3(4):1005.

33. Gutema GB, Gadisa DA, Kidanemariam ZA, Berhe DF, Berhe AH, Hadera MG, Hailu GS, Abrha NG. Self-medication practices among health sciences students: the case of Mekelle University. Journal of Applied Pharmaceutical Science. 2011 Dec 1;1(10):183.

34. Beyene A, Getachew E, Doboch A, Poulos E, Abdurahman K. Knowledge, attitude and practice of self medication among pharmacy students of rift Valley University, Abichu campus, Addis Ababa, Ethiopia. J Health Med Informat. 2017;8(269):2.

35. Al-Hussaini M, Mustafa S, Ali S. Self-medication among undergraduate medical students in Kuwait with reference to the role of the pharmacist. Journal of research in pharmacy practice. $2014 \mathrm{Jan} ; 3(1): 23$.

36. Klemenc-Ketis Z, Hladnik Z, Kersnik J. Self-medication among healthcare and non-healthcare students at University of Ljubljana, Slovenia. Medical Principles and practice. 2010;19(5):395-401.

37. Albashtawy M, Batiha A, Tawalbeh L. Self-Medication Among School Students. J Sch Nurs. 2015;31(2):110-6.

38. Lukovic JA, Miletic V, Pekmezovic T, Trajkovic G, Ratkovic N, Aleksic D, Grgurevic A. Self-medication practices and risk factors for self-medication among medical students in Belgrade, Serbia. PloS one. 2014 Dec 11;9(12):e114644.

39. Okyay RA, Erdoğan A. Self-medication practices and rational drug use habits among university students: a cross-sectional study from Kahramanmaraş, Turkey. PeerJ. 2017 Nov 1;5:e3990.

40. El Nimr NA, Wahdan IM, Wahdan AM, Kotb RE. Self-medication with drugs and complementary and alternative medicines in Alexandria, Egypt: prevalence, patterns and determinants. EMHJ-Eastern Mediterranean Health Journal. 2015;21(4):256-65.

41. Johny S, Torgal S, Mathew A. Assessment of Knowledge, Attitude and Practice of Self-medication among Second Year MBBS Students. Indian Journal of Pharmacology. 2017;4(1):42-4.

42. Ibrahim NK, Alamoudi BM, Baamer WO, Al-Raddadi RM. Self-medication with analgesics among medical students and interns in King Abdulaziz University, Jeddah, Saudi Arabia. Pakistan journal of medical sciences. 2015 Jan;31(1):14.

43. Sawalha AF, Sweileh WM, Sa'ed HZ, Jabi SW. Self-therapy practices among university students in Palestine: focus on herbal remedies. Complementary therapies in medicine. 2008 Dec 1;16(6):343-9.

44. Ouédraogo DD, Zabsonré JW, Tiendrebeogo EZ, Kakpovi KG, Kaboré F, Drabo JY, Guissou IP. Prevalence and factors associated with self-medication in rheumatology in Sub-Saharan Africa. European journal of rheumatology. 2015 Jun;2(2):52.

45. Patil SB, Vardhamane SH, Patil BV, Santoshkumar J, Binjawadgi AS, Kanaki AR. Self-medication practice and perceptions among undergraduate medical students: a cross-sectional study. Journal of clinical and diagnostic research: JCDR. 2014 Dec;8(12):HC20. 
46. Helal RM, Abou-EIWafa HS. Self-medication in university students from the city of Mansoura, Egypt. Journal of environmental and public health. 2017;2017.

47. Parulekar ME, Mekoth NA, Ramesh CM, Parulekar AJ. Self medication in developing countries a systematic review.

\section{Tables}

Table 1 Descriptive summary of studies included in the meta-analysis of the prevalence and determinants of self-medication among university students in Ethiopia 2018.

\begin{tabular}{|c|c|c|c|c|c|c|c|c|c|c|}
\hline s.no & Author & $\begin{array}{l}\text { Year } \\
\text { study } \\
\text { conducted }\end{array}$ & Region & University & $\begin{array}{l}\text { Study } \\
\text { design }\end{array}$ & $\begin{array}{l}\text { Sampling } \\
\text { technique }\end{array}$ & $\begin{array}{l}\text { Sampling } \\
\text { technique }\end{array}$ & $\begin{array}{l}\text { Prevalence } \\
(\%)\end{array}$ & $\begin{array}{l}\text { Response } \\
\text { rate (\%) }\end{array}$ & $\begin{array}{l}\text { Quality } \\
\text { score(10pts) }\end{array}$ \\
\hline 1 & $\begin{array}{l}\text { Abay } \\
\text { SM,AmeloW[27] }\end{array}$ & 2010 & Amhara & Gondar & $\begin{array}{l}\text { Cross- } \\
\text { sectional }\end{array}$ & Stratified & 414 & 38.50 & $\begin{array}{l}\text { not } \\
\text { stated }\end{array}$ & 7 \\
\hline 2 & $\begin{array}{l}\text { Dessalegn } \\
\text { Asmelashe,Gashaw } \\
\text { Binega[30] }\end{array}$ & 2017 & Amhara & Gondar & $\begin{array}{l}\text { Cross- } \\
\text { sectional }\end{array}$ & Stratified & 404 & 35.30 & 95.3 & 7 \\
\hline 3 & $\begin{array}{l}\text { Shimelis A,et.al } \\
\text { [28] }\end{array}$ & 2016 & Oromia & Arsi & $\begin{array}{l}\text { Cross- } \\
\text { sectional }\end{array}$ & Stratified & 548 & 77.10 & 95.3 & 8 \\
\hline 4 & Tadele Eticha[25] & 2014 & Tigrai & Mekelle & $\begin{array}{l}\text { Cross- } \\
\text { sectional }\end{array}$ & Stratified & 407 & 44.50 & 96.4 & 8 \\
\hline 5 & Abebe D, et.al.[29] & 2017 & Amhara & $\begin{array}{r}\text { Debre } \\
\text { markos }\end{array}$ & $\begin{array}{l}\text { Cross- } \\
\text { sectional }\end{array}$ & $\begin{array}{l}\text { Simple } \\
\text { random } \\
\text { sampling }\end{array}$ & 250 & 58.4 & 90.3 & 7 \\
\hline 6 & $\begin{array}{l}\text { Dessalegn } \\
\text { Asmelashe[31] }\end{array}$ & 2017 & Amhara & Gondar & $\begin{array}{l}\text { Cross- } \\
\text { sectional }\end{array}$ & Stratified & 404 & 32.70 & 95.3 & 7 \\
\hline 7 & $\begin{array}{l}\text { Alemseged B1, } \\
\text { et.al [34] }\end{array}$ & 2017 & Oromia & Riftvalley & $\begin{array}{l}\text { Cross- } \\
\text { sectional }\end{array}$ & Convenient & 400 & 72.8 & 90.2 & 7 \\
\hline 8 & Girma B, et.al [33] & 2011 & Tigrai & Mekelle & $\begin{array}{l}\text { Cross- } \\
\text { sectional }\end{array}$ & Stratified & 283 & 43.24 & $92.20 \%$ & 7 \\
\hline 9 & $\begin{array}{l}\text { Mulugeta T* and } \\
\text { Nasir T[32] }\end{array}$ & 2012 & Oromia & Jimma & $\begin{array}{l}\text { Cross } \\
\text { sectional }\end{array}$ & $\begin{array}{l}\text { Simple } \\
\text { random } \\
\text { sampling }\end{array}$ & 403 & 45.89 & 100 & 8 \\
\hline
\end{tabular}

Table 2 common sign and symptoms, commonly used drugs/group of drug used, reason for self -medication and recall period systemic review and meta-analysis among university students in Ethiopia, 2018 


\begin{tabular}{|c|c|c|c|}
\hline hor & & Common sign and symptoms & Drug /drug group used \\
\hline AmeloW[25] & 2010 & $\begin{array}{l}\text { Fever and Headache (25.8\%) } \\
\text { Cough and Common cold }(23.9 \%), \\
\text { Gastric pain }(13.2 \%), \\
\text { Diarrhea }(8.9 \%), \\
\text { Fever and Chills (6.1\%), } \\
\text { Cough and chest pain }(6.1 \%), \\
\text { Constipation (5.6\%), } \\
\text { Eye disease (3.8\%), } \\
\text { Other (stress, fatigue, loss ofappetite) }(6.5 \%)\end{array}$ & $\begin{array}{l}\text { Paracetamol, that is, }(46.3 \%) \text { analg } \\
\text { Anti-helminthes }(10.9 \%) \\
\text { Antibiotics }(4.8 \%) \\
\text { and anti- malarial }(3.7 \%)\end{array}$ \\
\hline $\begin{array}{l}\text { isalegn } \\
\text { nelashe,Gashaw } \\
\text { ega[28] }\end{array}$ & 2017 & NR & $\begin{array}{l}\text { Antibiotics (59.9\%), } \\
\text { Analgesics or antipyretics }(47.8 \%), \\
\text { Gastro intestinal drugs (28.8\%), } \\
\text { Respiratory tract infection drugs (24 }\end{array}$ \\
\hline $\begin{array}{l}\text { melis A, et.al } \\
\text { ] }\end{array}$ & 2016 & $\begin{array}{l}\text { Headache/fever (56.5\%), } \\
\text { Gastrointestinal disease(34.1), } \\
\text { Respiratory tract infection (31.8\%), } \\
\text { Eye disease (22.4\%), } \\
\text { Skin diseases or injury(17.45), } \\
\text { Sexually transmitted disease (10.4\%), } \\
\text { Maternal/menstrual }(29.2 \%)\end{array}$ & $\begin{array}{l}\text { Amoxicillin (43.3\%), } \\
\text { Ampicillin (18.4\%), } \\
\text { Ciprofloxacin }(12.9 \%) \text {, } \\
\text { Doxycycline }(9.2 \%), \\
\text { Metronidazole }(5.5 \%), \\
\text { Tetracycline }(5.5 \%), \\
\text { Others }(5.1 \%)\end{array}$ \\
\hline lele Eticha[23] & 2014 & $\begin{array}{l}\text { Cough Common cold (43.85), headache (34.8\%), and Abdominal pain } \\
\text { (32.1\%), } \\
\text { Fever (24.1\%), Diarrhea (19.6\%), } \\
\text { Eye infection(15.2), Nasal congestion(14.3), } \\
\text { Tooth ache }(12.55), \\
\text { Sore throat }(12.5 \%), \text { Others }(17.9 \%)\end{array}$ & $\begin{array}{l}\text { Amoxicillin (43.3\%), } \\
\text { Ampicillin (18.4\%), } \\
\text { Ciprofloxacin }(12.9 \%) \text {, } \\
\text { Doxycycline }(9.2 \%), \\
\text { Metronidazole }(5.5 \%) \text {, } \\
\text { Tetracycline }(5.5 \%) \text {, Others }(5.1 \%)\end{array}$ \\
\hline $\begin{array}{l}\text { sbe D, et.al } \\
\text { 7] }\end{array}$ & 2017 & $\begin{array}{l}60(41 \%), 24(16.4 \%), 17(11.6 \%), 14(9.6 \%), 11(7.5 \%), 10(6.8 \%) \text { and } \\
10(6.8 \%) \text { identified pain (head, body, tooth), diarrhea, fever, nausea and } \\
\text { vomiting, dysmenorrhea, cough and itching respectively }\end{array}$ & Analgesics (52.7\%), antifungals (2.1 \\
\hline $\begin{array}{l}\text { isalegn } \\
\text { nelashe[29] }\end{array}$ & 2017 & $\begin{array}{l}\text { headache (69.1\%), common cold (15.9\%), fever (15.9\%), and abdominal } \\
\text { discomfort (15.1\%),Appetite loss(7.9\%), Nausea and vomiting (7.1\%),Heart } \\
\text { burn/ } \\
\text { gastritis(6.3\%),Diarrhea(5.6\%),Impotence(5.6\%),Contraception(4.8\%), Eye } \\
\text { disease(4\%),Skin condition(0.8\%) }\end{array}$ & $\begin{array}{l}\text { Analgesics }(N=67,53.2 \%) \text { antimic } \\
\text { Vitamins }(8.7 \%)\end{array}$ \\
\hline $\begin{array}{l}\text { mseged B1, } \\
\text { ll [32] }\end{array}$ & 2017 & $\begin{array}{l}\text { Fever and headache(69.3\%), Gastric pain(67.5\%),Cough and common } \\
\text { cold(46.3\%),Cough and chest pain(46\%),Constipation(30\%),Vomiting and } \\
\text { diarrhea(29.5\%),Fever and chills(23.8\%),Skin symptoms(15.8\%),Ear } \\
\text { symptoms(15.5\%),Others(7\%) }\end{array}$ & Paracetamol(92\%),Antacid(71.8\%), \\
\hline ma B, et.al [31] & 2011 & $\begin{array}{l}\text { Headache or mild pain (47.3\%), GI problems(30.8\%) } \\
\text { Eye and ear symptoms (29.1\%) Vomiting }(6.3 \%)\end{array}$ & $\begin{array}{l}\text { Antibiotic (47\%), pain killer }(37 \% \\
(7 \%) \text {,other }(2 \%)\end{array}$ \\
\hline $\begin{array}{l}\text { lugeta T* and } \\
\text { sir T[30] }\end{array}$ & 2012 & $\begin{array}{l}\text { Headache } 35(36.85 \%) \text {, abdominal pain } 29(30.55 \%) \text { and cough } 33 \\
(23.16 \%) \text {, Fever }(6.32 \%) \text { Other }(3.12 \%)\end{array}$ & Analgesics 40(49.38\%), antibiotics \\
\hline
\end{tabular}

Table 3 source of information and source of drugs for self-medication among university students in Ethiopia systemic review and metaanalysis, 2018 


\begin{tabular}{|c|c|c|c|}
\hline hor & & Suggested by & Source of drug \\
\hline $\begin{array}{l}\text { ay } \\
\text { AmeloW[25] }\end{array}$ & 2010 & $\begin{array}{l}\text { Friends constituted } 19.5 \% \\
\text { reading material } 30.5 \% \text {, } \\
\text { traditional healers } 3.7 \% \text {, and } \\
\text { others } 7.3 \%\end{array}$ & $\begin{array}{l}\text { (72\%) obtained drugs from the pharmacy or drug shop } \\
\text { without prescription, }(5.9 \%) \text {; } \\
\text { From their friends, (3.6\%); from drugs left over from } \\
\text { prior use, and the remaining ( } 8.5 \%) \text { from plant } \\
\text { (traditional medicines). }\end{array}$ \\
\hline $\begin{array}{l}\text { isalegn } \\
\text { nelashe,Gashaw } \\
\text { ega[28] }\end{array}$ & 2017 & $\begin{array}{l}\text { Relatives and friends (35.8\%), } \\
\text { Health professionals (32.5\%), } \\
\text { Media advertisement (27\%), } \\
\text { Internet }(19.2 \%), \\
\text { Textbooks }(13.8 \%) \text {, } \\
\text { Drug leaflet }(10.7 \%)\end{array}$ & NR \\
\hline $\begin{array}{l}\text { melis A,et.al } \\
\text { ]] }\end{array}$ & 2016 & $\begin{array}{l}\text { Family }(17.1 \%), \\
\text { Friends }(21.4 \%), \\
\text { Own experience }(51.5 \%) \text {, } \\
\text { Previous doctor prescription }(27.1 \%), \\
\text { Advice From pharmacy } \\
\text { professionals32.8\%) }\end{array}$ & $\begin{array}{l}\text { Government pharmacy }(52.7 \%), \\
\text { Private pharmacy }(36.9 \%), \\
\text { From previous leftover drugs }(24.2 \%) \text {, } \\
\text { Relatives and friends }(6.8 \%), \\
\text { Supermarket }(2.3 \%)\end{array}$ \\
\hline $\begin{array}{l}\text { sbe D, et.al. } \\
\text { ] }\end{array}$ & 2017 & NR & (2) \\
\hline $\begin{array}{l}\text { isalegn } \\
\text { nelashe[29] }\end{array}$ & 2017 & NR & $\mathrm{NR}$ \\
\hline $\begin{array}{l}\text { mseged B1, } \\
\text { ll [32] }\end{array}$ & 2017 & $\begin{array}{l}\text { Reading materials and medical books } \\
\text { (56.3\%), } \\
\text { Advice from pharmacists (43.8\%), } \\
\text { Advice from physician/nurse but without } \\
\text { prescriptions (38.8\%), } \\
\text { My own experience (37.3\%), } \\
\text { Others (internet and advertisement) } \\
\text { (19.3\%), } \\
\text { Advice from classmate friend (15\%), } \\
\text { Advice from traditional healers }(9.8 \%)\end{array}$ & NR \\
\hline $\begin{array}{l}\text { lugeta T* and } \\
\text { sir T[30] }\end{array}$ & 2012 & $\begin{array}{l}\text { My self- decision }(34.74 \%), \\
\text { Family }(27.37 \%), \\
\text { Friends }(20 \%) \text {, } \\
\text { Health professionals }(17.89 \%) \\
\end{array}$ & $\begin{array}{l}\text { Drug outlets (92.63\%), } \\
\text { Shops/supermarkets }(3.16 \%), \\
\text { Relatives }(3.16 \%), \\
\text { Left over medicine from previous medicine }(1 \%)\end{array}$ \\
\hline
\end{tabular}

Table 4 Sub-group analysis prevalence of self-medication among university in Ethiopia by region, 2018.

\begin{tabular}{|lcccc|}
\hline Subgroup & No of studies & prevalence & Test of heterogeneity & P-value \\
\hline Oromia & 3 & $57.78(24.47,91.18)$ & $99.5 \%$ & 0.001 \\
Amhara & 4 & $36.43(22.08,50.78)$ & $97.3 \%$ & 0.001 \\
Tigray & 2 & $43.91(40.21,47.61)$ & $0 \%$ & 0.723 \\
\hline
\end{tabular}

\section{Supporting Information}

S1 Table. PRISMA checklist.

S2 Table. List of Tables.

S3. Newcastle data quality Assessment

\section{Figures}




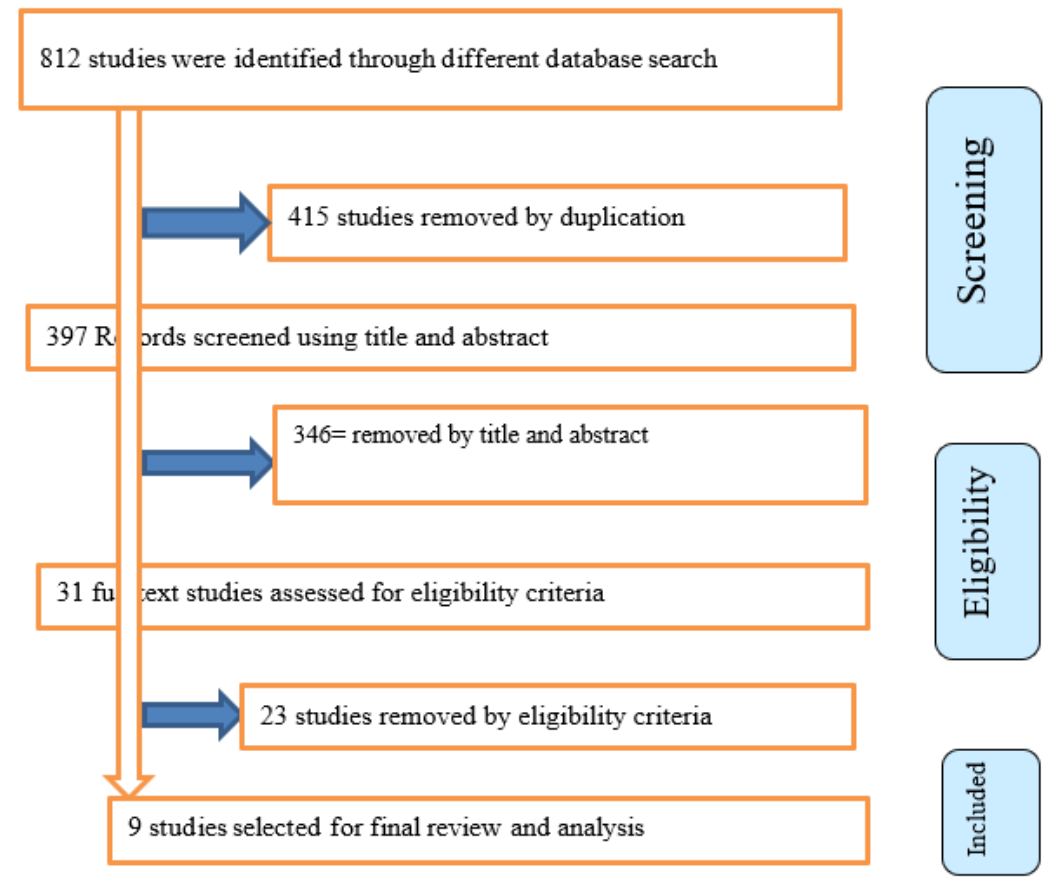

\section{Figure 1}

Flow chart describing the selection of studies for the systematic review and meta-analysis of prevalence and predictors of self-medication among university students in Ethiopia, 2018.

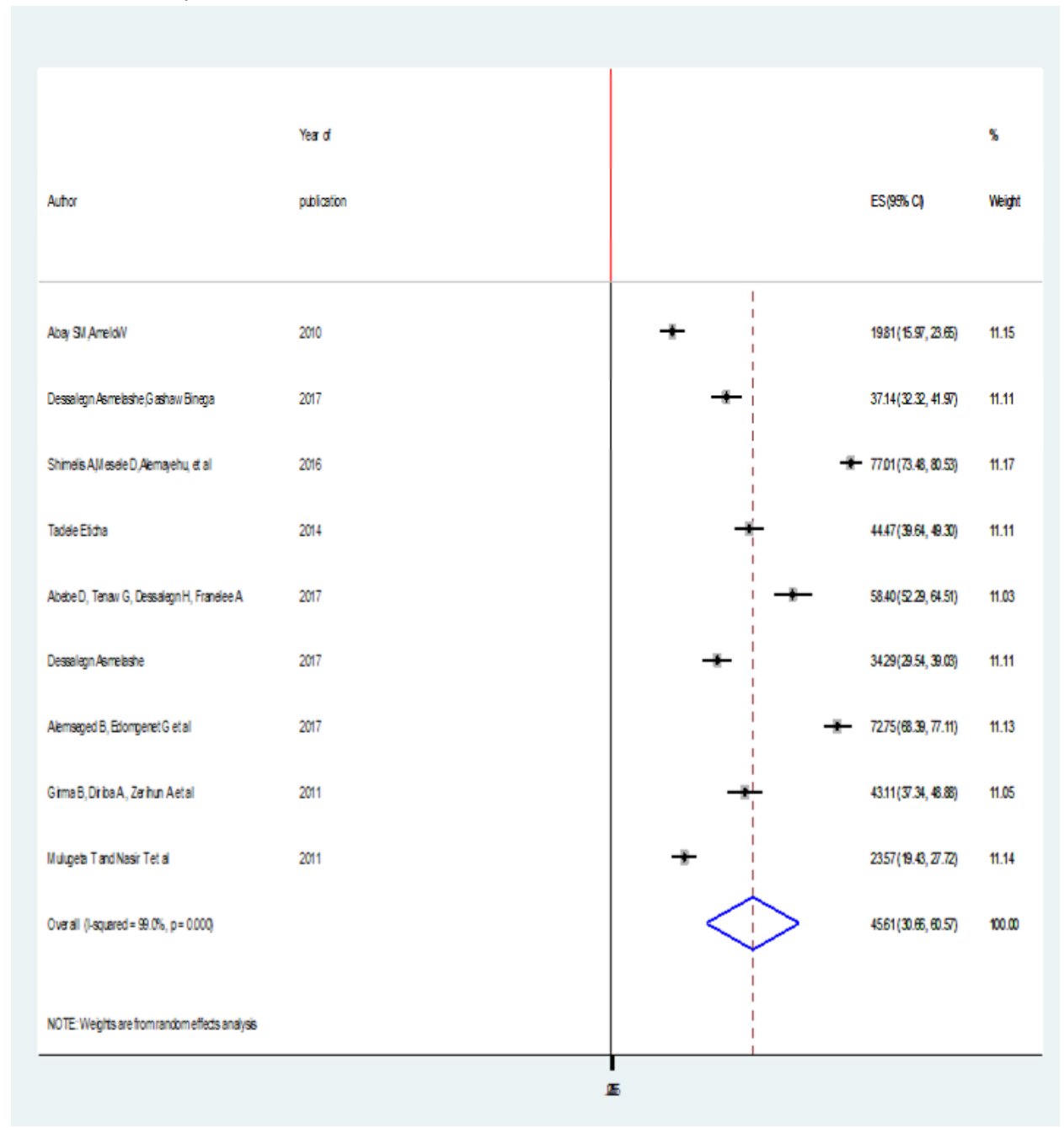

Figure 2

Page $11 / 13$ 
Forest plot of the pooled prevalence of self-medication among university students in Ethiopia.

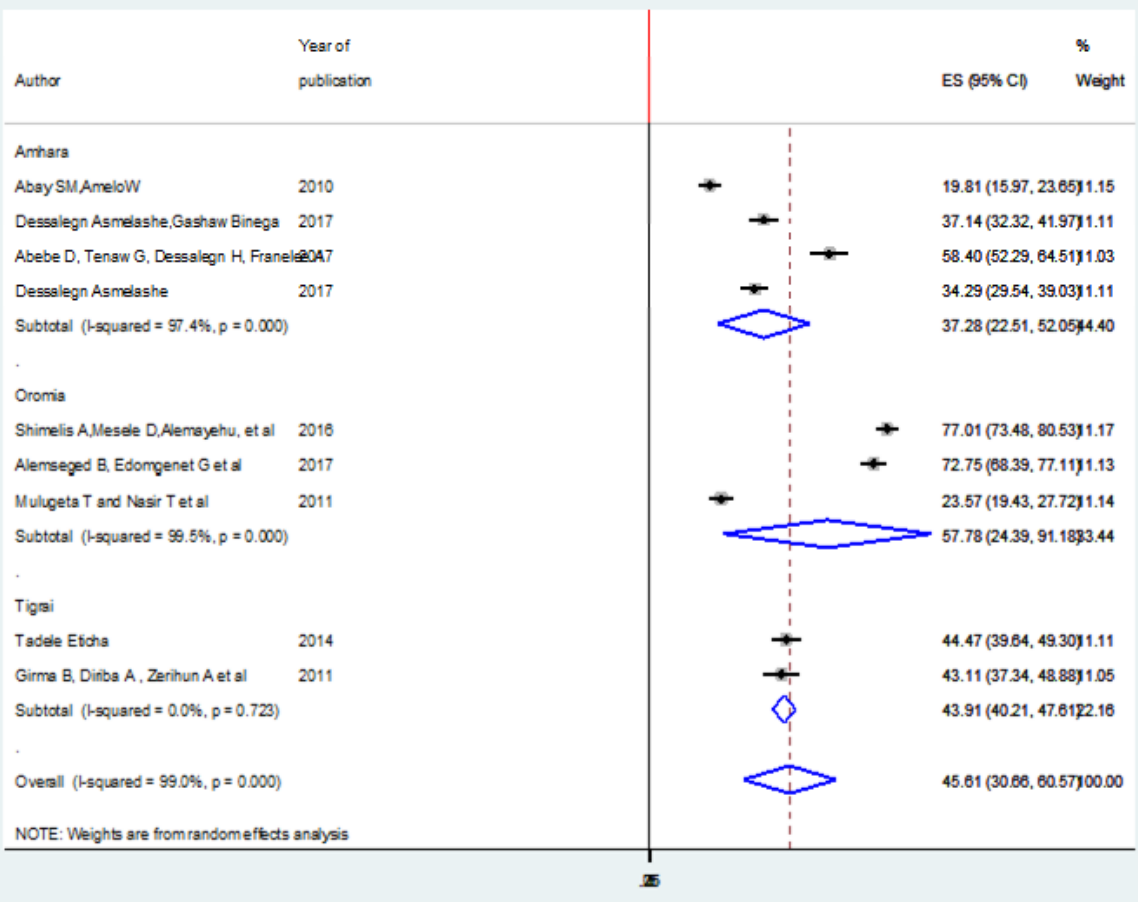

\section{Figure 3}

The pooled estimated prevalence of self-medication among university students by region among in Ethiopia, 2018.

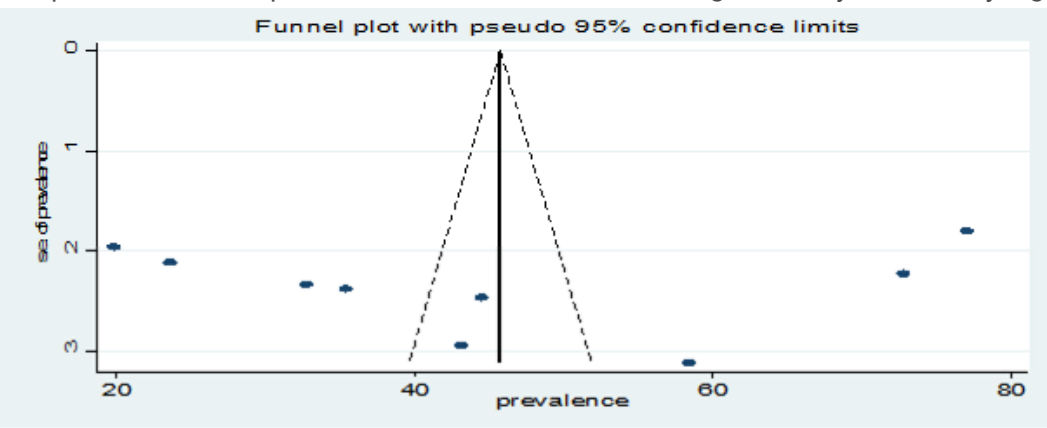

\section{Figure 4}

Funnel plot with $95 \%$ confidence limits of the pooled prevalence of self-medication among university students in Ethiopia.

\section{Figure 5}

Sensitivity analysis for single study influence of self-medication prevalence in Ethiopia, 2019.

\section{Figure 6}

The pooled odds ratio of the association between sex and self-medication among university students in Ethiopia, 2018.

\section{Figure 7}

The pooled odds ratio of the association between year of study and self-medication among university students in Ethiopia, 2018. 


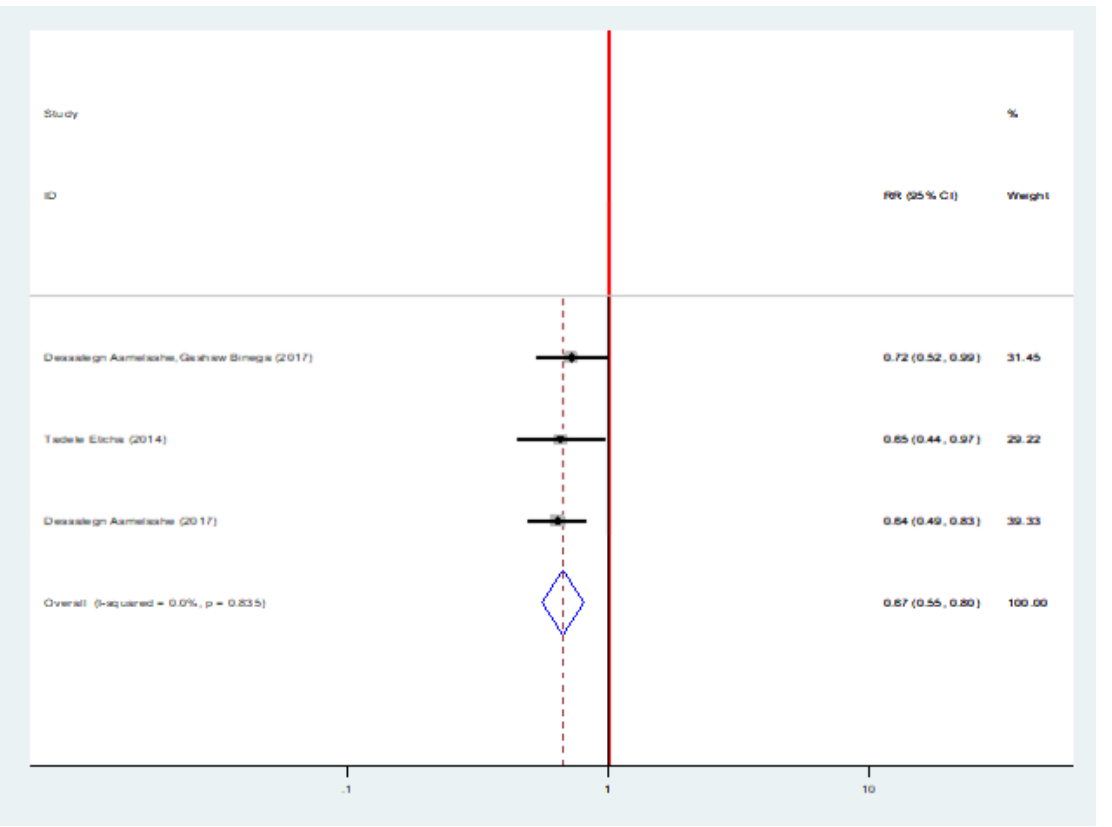

Figure 8

The pooled odds ratio of the association between income level and self-medication among university students in Ethiopia, 2018.

\section{Supplementary Files}

This is a list of supplementary files associated with this preprint. Click to download.

- prismachecklist.pdf

- qualityassessment.pdf 